\title{
BIMBINGAN PENYUSUNAN LAPORAN KEUANGAN YAYASAN DARUL FALAH BERDASARKAN STANDAR AKUNTANSI KEUANGAN
}

\author{
Ardiansyah $^{1}$ \\ ${ }^{1}$ Politeknik Negeri Ambon \\ Email : ardi4n.1410@gmail.com
}

\begin{abstract}
ABSTRAK
Yayasan Darul Falah Kab. Bantaeng, Provinsi Sulawesi Selatan sebagai salah satu organisasi nirlaba yang bergerak dibidang pendidikan berkewajiban menyusun laporan keuangan sesuai standar akuntansi agar Dana ummat dapat produktif dan tepat sasaran sekaligus untuk memberikan keyakinan dan menjaga kepercayaan pihak internal dan eksternal yayasan. Namun, sistem pencatatan hingga pelaporan keuangannya yang menggunakan Microsoft excel pada neraca tidak balance (seimbang) sehingga sudah pasti terdapat kesalahan pada siklus akuntansi yang telah dilakukan akibat ketidaksengajaan dan belum dipahaminya dengan baik ketentuan pelaporan keuangan yayasan yang berbeda dengan perusahaan. Oleh karena itu, pengabdian ini dalam bentuk bimbingan penyusunan laporan keuangan dilakukan untuk menjawab kebutuhan dan kendala pihak yayasan melalui zoom claud meeting yang record zoom claud meeting diuplaod via youtube dengan status not public. Hasil dari kegiatan ini terlihat pada laporan keuangan yayasan yang sudah balance (seimbang) dan meningkatnya SDM (Sumber Daya Manusia) pihak yayasan sehingga dengan disusunnya laporan keuangan sesuai standar akuntansi keuangan dapat memberikan kepercayaan atas akuntabilitas dan profesinalisme pengelololaan keuangan yayasan baik kepada pihak internal maupun eksternal.
\end{abstract}

Kata kunci: Bimbingan, Standar, Akuntansi, dan Yayasan. 


\section{PENDAHULUAN}

Berdirinya sebuah organisasi tentunya untuk mencapai tujuan awal yang telah ditetapkan sesuai klasifikasi organisasi tersebut, salah satunya adalah yayasan yang merupakan salah satu organisasi non profit motif atau nir laba (Aldiansyah dan Lambey, 2017). Yayasan terinstitusionalisasi sekaligus sebagai entitas jasa sukarelawan yang bertujuan untuk kepentingan ummat dan berpartisifasi mencerdaskan generasi bangsa melalui pendirian sekolah dan pondok pesantren. Hal ini pula yang menjadi motivasi para donatur dalam memberikan bantuan dana sosial melalui proyekproyek amal (Utomo dan Qomariah, 2014). Secara perinsip organisasi non profit motif memiliki perbedaan yang cukup signifikan dengan organisasi profit motif, diiantara perbedaannya terletak pada cara memperoleh sumber daya keuangan dan pengalokasiannya. Secara khusus organisasi nir laba (yayasan) memperoleh sumber daya yang dibutuhkan untuk melakukan berbagai aktivitas operasionalnya (Anand, 2018).

Peningkatan SDM (Sumber Daya Manusia) dalam melakukan manajemen akuntansi keuangan organisasi nir laba dalam bentuk yayasan merupakan hal yang sangat penting demi memberikan kepercayaan kepada donatur yang berharap dana yang disumbangkan dapat dimanfaatkan untuk kepetingan ummat baik dalam bentuk zakat, infak/sedekah dan wakaf. Terkhusus dana infak/sedekah dan wakaf yang harus dimanajememi secara produktif sehingga dapat menjadi instrumen memajukan kesejahteraan ekonomi ummat (Syaifullah dan Idrus, 2019). Pelaporan keuangan dengan mendasarkan pada prinsip kejujuran, kebenaran dan keadilan baik dalam lingkup organisasi profit motif maupun non profit motif (Amin dan Astuti, 2019).

Indikator utama dalam mengukur kinerja keuangan suatu organisasi adalah laporan keuangan yang sistematis, akuntabel, valid dan dapat dipertanggung jawabkan serta terbuka untuk diaudit. Pemenuhan standar sebagai suatu kepatuhan dalam memelihara akuntabilitas laporan keuangan demi kepercayaan masyarakat terhadap pengelolaan dana ummat sekaligus menjamin pemanfaatan dana untuk proyek amal. Laporan keuangan dan laporan program untuk memberikan keyakinan yang memadai 
kepada seluruh pengguna laporan keuangan dan laporan aktivitas pengelolaan dana ummat.

Dengan adanya standar pelaporan, diharapkan laporan keuangan entitas nirlaba dapat lebih mudah dipahami, rasional, dan akuntabel. Tidak terkecuali pihak Yayasan Darul Falah sebagai organisasi nirlaba yang berorientasi dibidang pendidikan sehingga penyusunan laporan keuanganya memiliki beberapa perbedaan penting dengan perusahaan. Pernyataan Standar Akuntansi Keuangan (PSAK) 45 adalah standar yang sesuai untuk diimplementasikan pada yayasan pendidikan yang tidak berorientasi laba (Biduri dkk, 2020).

Dalam hal laporan keuangan Yayasan Darul Falah yang sudah terkomputerisasi dengan berusaha mengoptimalkan microsoft excel tetapi neracanya ternyata tidak balance, maka hal ini merupakan kebutuhan dan kendala pihak yayasan yang membutuhkan bimbingan, arahan dan telaah terhadap akun-akun keuangan dalam memahami laporan keuangan secara baik sesuai standar akuntansi keuangan. Untuk itu pengabdi memberikan bimbingan dalam penyusunan laporan keuangan Yayasan Darul Falah Kabupaten Bantaeng, Provinsi Sulawesi Selatan.

\section{METODE}

Metode pelaksanaan kegiatan pengabdian ini adalah pemberian materi berdasarkan kendala dan permasalahan pada laporan keuangan Yayasan Darul Falah yang tidak sesuai dengan Standar Akuntansi Keuangan. Laporan keuangan Yayasan Darul Falah berbasis komputerisasi dengan menerapkan siklus akuntansi mulai dari jurnal, buku besar hingga neraca. Namun, neracanya sebelum dilakukan pengabdian ini tidak balance (seimbang) sehingga keberhasilan pengabdian ini dapat dilihat dari posisi neraca pada laporan keuangan Yayasan Darul Falah yang sudah seimbang (balance) dan meningkatnya Sumber Daya Manusia (SDM) yang dimiliki oleh bendaharawan. Adapun tahapan pelaksanaan pembimbingan ini untuk mencapai tujuan bimbingan dalam menyelesaikan permaslahan mitra adalah, sebagai berikut:

\subsection{Perencanaan}

Kegiatan pengabdian ini diawali dengan permasalahan yang muncul dari 
laporan keuangan Yayasan Darul Falah yang pada neracanya tidak balance, maka dilakukanlah analisis awal penyebab ketidak seimbangnya neraca tersebut, karena dalam ilmu akuntansi jika neraca tidak balance sudah pasti salah dan meskipun neraca balance belum tentu benar. Perencanaan awal menentukan tempat pelaksanaan, berhubung pengabdi berada diwilayah provinsi yang berbeda dengan mitra dan untuk memudahkan proses bimbingan berlangsung sehingga waktu pelaksanaan lebih fleksibel maka, disepakati untuk proses bimbingan dilakukan secara daring (dalam jaringan) melalui zoom claud meeting. Konsep pendekatan andragogi berbasis telaah dan praktik tetap dipertahankan meskipun dilakukan secara daring (Nizaruddin dkk, 2020).

Disamping itu dengan menggunakan zoom calud meeting, setiap pertemuan dapat di rekam (record zoom) dan hasil record zoom tersebut di upload via youtube sehingga dapat di review, dipelajari kembali kapanpun dan dimanapun oleh pihakpihak terkait. Record zoom yang di upload via youtube disetiap selesai bimbingan dengan sengaja di setting not public karena memuat informasi keuangan yayasan termasuk gaji dan honor para guru/ustadz yang kurang tepat dikonsumsi masyarakat luas.

Perencanaan bukan hanya dilakukan diawal, namun selalu dipantau perkembangan bendaharawan dalam memahami materi dan pejelasan serta simulasi yang diberikan disetiap pertemuan sekaligus untuk menentukan topik pembahasan dipertemuan berikutnya sesuai kebutuhan mantra dan untuk memperdalam pemahaman serta soft skill mitra.

\subsection{Pelaksanaan}

Proses bimbingan yang dilakukan secara daring dengan total durasi bimbingan 7 jam, 54 menit, 29 detik. Durasi pelaksanaan bimbingan tersebut sesuai waktu efektif bimbingan berdasarkan record zoom claud meeting yang telah upload via youtube dengan status not public. Adapun tanggal pelaksanaan, materi/topik pembahasan dan durasi pelaksanaan bimbingan penyusunan laporan keuangan Yayasan Darul Falah berdasarkan standar akuntansi Keuangan dapat dilihat pada tabel 1. 
Tabel 1. tanggal pelaksanaan, materi/topik pembahasan dan durasi pelaksanaan bimbingan penyusunan laporan keuangan Yayasan Darul Falah berdasarkan standar akuntansi Keuangan

\begin{tabular}{|c|c|c|c|}
\hline $\begin{array}{c}\text { Pertemuan } \\
\mathrm{Ke}\end{array}$ & $\begin{array}{l}\text { Tanggal } \\
\text { (Pukul) }\end{array}$ & Pembahasan & $\begin{array}{c}\text { Durasi } \\
\text { Pelaksanaan }\end{array}$ \\
\hline 1 & $\begin{array}{c}03-10-2020 \\
(14.15 \text { s.d } \\
15.03 \text { WIT, } \\
16.19 \text { s.d } \\
17.29 \text { WIT, } \\
17.09 \text { s.d } \\
17.59)\end{array}$ & $\begin{array}{l}\text { 1. Perbedaan Sistem akuntansi manual dan } \\
\text { komputerisasi } \\
\text { 2. Aturan pencantuman periode laporan } \\
\text { keuangan } \\
\text { 3. Simulasi perbedaan siklus akuntansi } \\
\text { laporan keuangan perusahaan dengan } \\
\text { yayasan } \\
\text { 4. Simulasi saldo awal periode, periode } \\
\text { berjalan dan saldo akhir periode } \\
\text { 5. Telaah akun; kas ditangan; kas di bank; } \\
\text { SWPS. } \\
\text { 6. Simulasi dan telaah mekanisme kerja jurnal } \\
\text { umum dan buku besar }\end{array}$ & 02:19:02 \\
\hline 2 & $\begin{array}{c}10-10-2020 \\
(08.26 \text { s.d } \\
10.11 \text { WIT })\end{array}$ & $\begin{array}{l}\text { 1. Telaah akun penerimaan SWPS } \\
\text { 2. Metode Pengakuan Harga Perolehan Aktiva } \\
\text { Tetap } \\
\text { 3. Fungsi nomor bukti transaksi } \\
\text { 4. Mekanisme siklus audit laporan keuangan } \\
\text { dan pentingnya bukti transaksi yang dapat } \\
\text { dipertanggungjawabkan } \\
\text { 5. Simulasi jurnal, buku besar, laporan laba } \\
\text { rugi, laporan perubahan ekuitas dan neraca } \\
\text { antara perusahaan dengan unsur-unsur } \\
\text { laporan keuangan yayasan, hukum balance, } \\
\text { 6. Ketentuan baku penamaan akun dalam ilmu } \\
\text { akuntansi, penggunaan materai, } \\
\text { kelengkapan bukti-bukti transaksi dan } \\
\text { berita acara pembayaran. }\end{array}$ & 01:45:08 \\
\hline 3 & $\begin{array}{c}18-10-2020 \\
(08.23 \text { s.d } \\
10.33 \text { WIT })\end{array}$ & $\begin{array}{l}\text { 1. Perbedaan hukum debet kredit di neraca } \\
\text { dengan buku besar } \\
\text { 2. Identifikasi bukti transaksi, } \\
\text { 3. Konsistensi Metode Penyusutan/Depresiasi } \\
\text { Aktiva Tetap } \\
\text { 4. Ketentuan menghitung harga perolehan, } \\
\text { estimasi nilai sisa dan estimasi umur } \\
\text { manfaat aktiva tetap }\end{array}$ & 02:09:48 \\
\hline 4 & $\begin{array}{c}24-10-2020 \\
(08.32- \\
10.13 \text { WIT })\end{array}$ & $\begin{array}{l}\text { 1. Metode pengakuan nilai residu/sisa dan } \\
\text { nilai ekonomis aktiva tetap } \\
\text { 2. Simulasi Penyusutan/Depresiasi Aktiva } \\
\text { Tetap dengan mengunakan metode garis } \\
\text { lurus }\end{array}$ & $01: 40: 31$ \\
\hline
\end{tabular}




\begin{tabular}{|c|c|c|}
\hline & $\begin{array}{ll}\text { 3. } & \text { Simulasi Penyusutan/Depresiasi Aktiva } \\
\text { Tetap dengan mengunakan metode saldo } \\
\text { menurun berganda }\end{array}$ & \\
\hline \multicolumn{2}{|r|}{ Total Jam Bimbingan } & 07:54:29 \\
\hline
\end{tabular}

\subsection{Evaluasi}

Evaluasi dilakukan terhadap laporan keuangan Yayasan Darul Falah yang telah direvisi berdasarkan standar akuntansi keuangan dan dengan cara tanya jawab secara langsung terhadap materi/topik pembahasan yang telah dijelaskan selama proses bimbingan berlangsung.

\section{HASIL DAN PEMBAHASAN}

Kegiatan ini dilaksanakan sebanyak 4 (empat) kali pertemuan dengan total jam bimbingan 7 Jam, 54 menit, 29 detik berdasarkan waktu efektif bimbingan pada record zoom claud meeting yang telah upload via youtube dengan status not public.

\subsection{Pertemuan Ke 1}

Pada pertemuan pertama dilakukan telaah terhdap laporan keuangan yang sudah dikirimkan sebelumnya oleh mitra pada saat perencanaan. Proses telaah dengan cara mendifinisikan setiap akun dan fungsi dari siklus akuntansi hingga peserta/bendahawaran/mitra memahami dengan jelas makna setiap akun yang dicantumkan dilaporan keuangan.
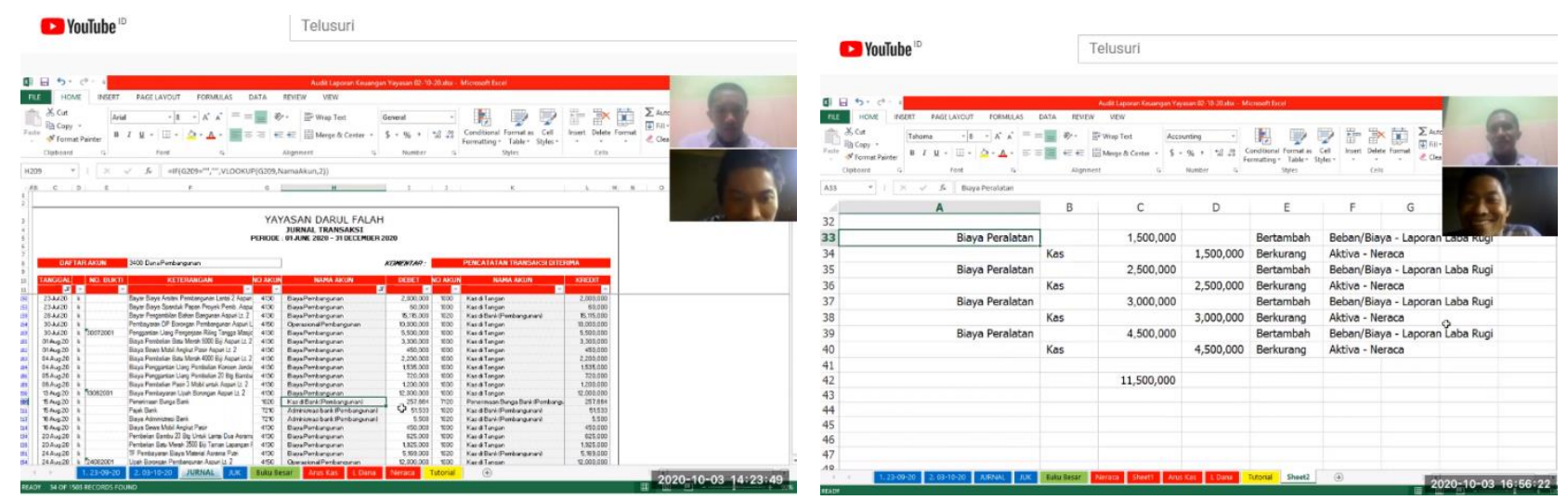


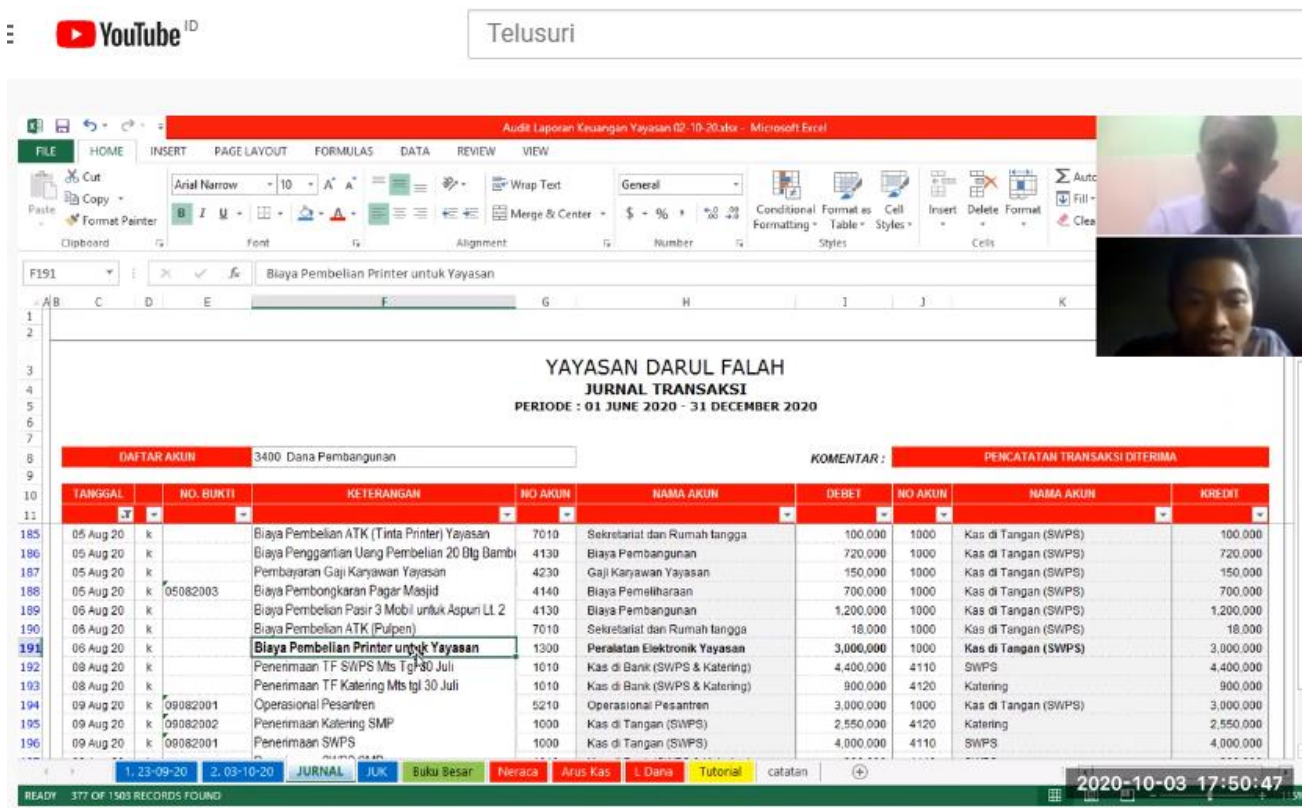

Pertemuan 1.3. Tgl. 031020. Pkl. 17.09 s.d 17.59 $\Leftrightarrow$ Tidak Publik

Gambar 1. Pertemuan 1 pada tanggal 03-10-2020 (Pukul: 14.15 s.d 15.03 WIT, 16.19 s.d 17.29 WIT, 17.09 s.d 17.59)

Proses pembimbingan dipertemuan 1 ini memakan waktu 2 jam, 19 menit, 2 detik yang secara rinci membahas tentang topik berikut ini:

a. Perbedaan Sistem akuntansi manual dan komputerisasi

b. Aturan pencantuman periode laporan keuangan

c. Simulasi perbedaan siklus akuntansi laporan keuangan perusahaan dengan yayasan

d. Simulasi saldo awal periode, periode berjalan dan saldo akhir periode

e. Telaah akun; kas ditangan; kas di bank; SWPS.

f. Simulasi dan telaah mekanisme kerja jurnal umum dan buku besar

\subsection{Pertemuan Ke 2}

Pada pertemuan kedua, dilakukan beberapa kali simulasi input, proses dan output. Dengan cara memberikan contoh transaksi sederhana untuk dijawab oleh mitra dan dijelaskan atau diklarifikasi jawban mitra tersebut dalam bentuk simulasi. 


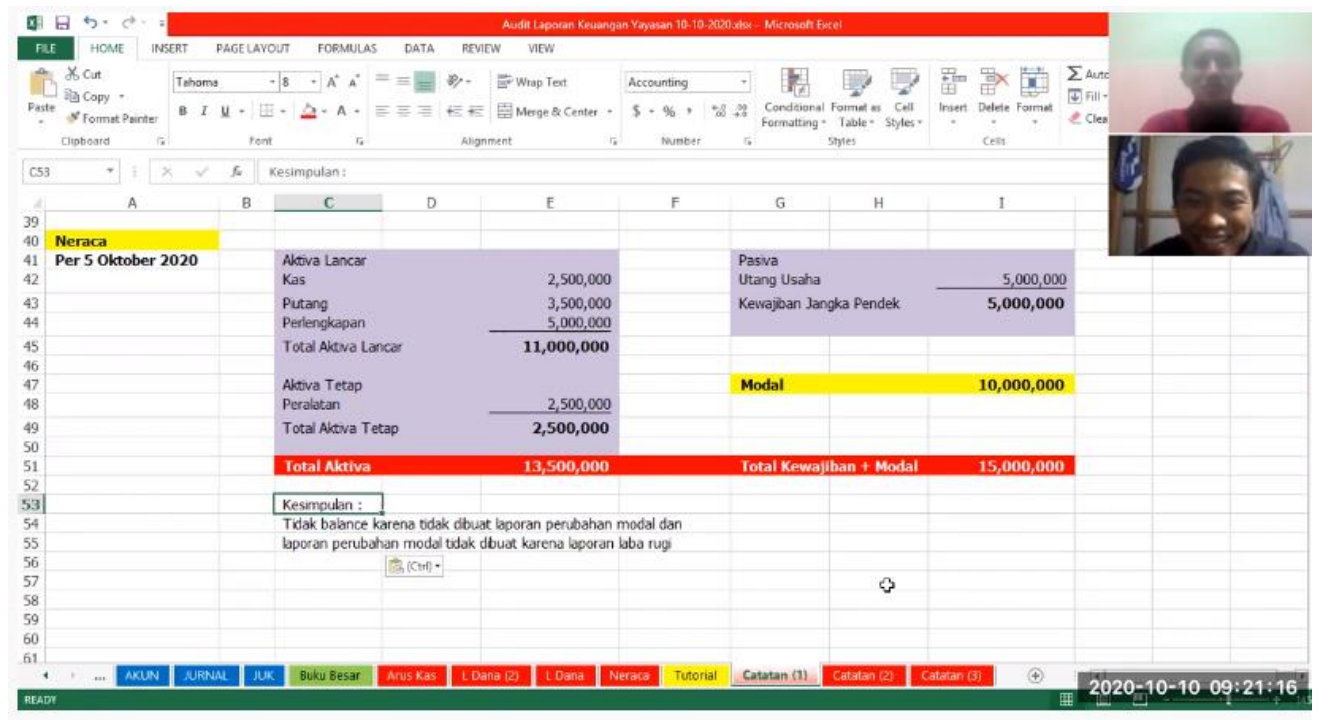

Pertemuan 2. Tgl. 101020. Pkl. 08.26 s.d 10.11 $\Leftrightarrow$ Tidak Publik

Gambar 2. Pertemuan 2 pada tanggal 10-10-2020 (Pukul : 08.26 s.d 10.11 WIT)

Proses pembimbingan dipertemuan 2 ini memakan waktu 1 jam, 45 menit, 8 detik yang secara rinci membahas tentang topik berikut ini:

a. Telaah akun penerimaan SWPS

b. Metode Pengakuan Harga Perolehan Aktiva Tetap

c. Fungsi nomor bukti transaksi

d. Mekanisme siklus audit laporan keuangan dan pentingnya bukti transaksi yang dapat dipertanggungjawabkan

e. Simulasi jurnal, buku besar, laporan laba rugi, laporan perubahan ekuitas dan neraca antara perusahaan dengan unsur-unsur laporan keuangan yayasan, hukum balance,

f. Ketentuan baku penamaan akun dalam ilmu akuntansi, penggunaan materai, kelengkapan bukti-bukti transaksi dan berita acara pembayaran.

\subsection{Pertemuan Ke 3}

Pada pertemuan ketiga, sebelum simulasi perhitungan harga peroleh dan depresiasi aktiva tetap dengan menggunakan metode garis lurus, terlebih dahulu dijelaskan kembali tentang siklus akuntansi dalam menghasilkan laporan keuangan. Bertujuan agar mitra memahami dampak jika, salah dalam menentukan nilai residu dan nilai ekonomis terhadap aktiva tetap yang akan dilakukan perhitungan harga perolehan serta melakukan simulasi posting transaksi di buku besar termasuk perbedaan hukum 
debet dan kredit dibuku besar dengan di neraca.

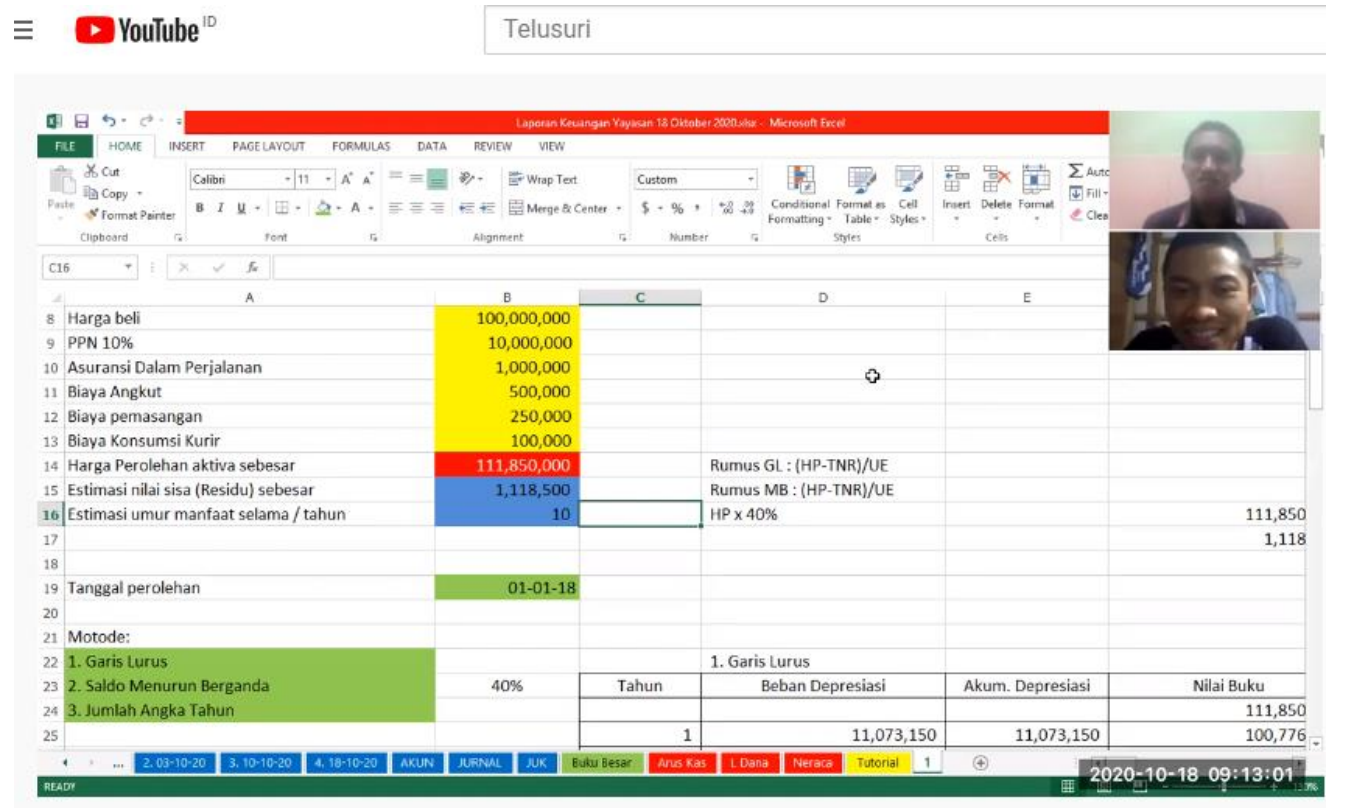

Pertemuan 3. Tgl. 181020. Pkl. 08:23-10:33 $\Leftrightarrow$ Tidak Publik

Gambar 3. Pertemuan 3 pada tanggal 18-10-2020 (Pukul: 08.23 s.d 10.33 WIT)

Proses pembimbingan dipertemuan 3 ini memakan waktu 2 jam, 9 menit, 48 detik yang secara rinci membahas tentang topik berikut ini:

a. Perbedaan hukum debet kredit di neraca dengan buku besar

b. Identifikasi bukti transaksi,

c. Konsistensi Metode Penyusutan/Depresiasi Aktiva Tetap

d. Ketentuan menghitung harga perolehan, estimasi nilai sisa dan estimasi umur manfaat aktiva tetap

\subsection{Pertemuan Ke 4}

Pada pertemuan keempat ini difokuskan untuk melakukan simulasi yang dimulai dari simulasi pembelian aktiva tetap baru, kemudian dilakukan perhitungan harga peroleh dan ketentuan dalam penilaian masa manfaat/ekonomis serta nilai residu suatu aktiva tetap baru dengan menggunakan 3 metode yang berbeda. Berdasarkan hasil pembimbingan dan interaktif dengan mitra, maka mitra memilih lebih tepat menggunakan metode depresiasi garis lurus terhadap seluruh asset yang dimiliki oleh Yayasan Darul Falah. 


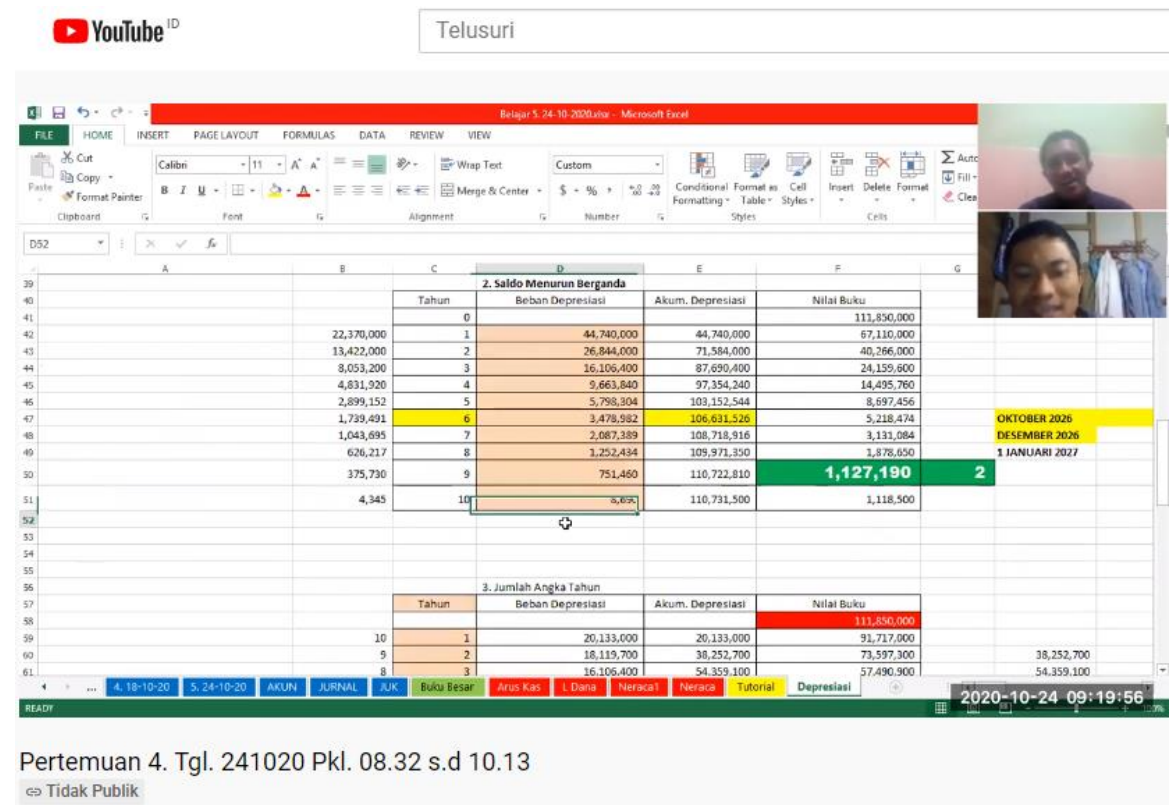

Gambar 3. Pertemuan 3 pada tanggal 24-10-2020 (Pukul: 08.32-10.13 WIT)

Proses pembimbingan dipertemuan 4 ini memakan waktu 1 jam, 40 menit, 31detik yang secara rinci membahas tentang topik berikut ini:

a. Metode pengakuan nilai residu/sisa dan nilai ekonomis aktiva tetap

b. Simulasi Penyusutan/Depresiasi Aktiva Tetap dengan mengunakan metode garis lurus

c. Simulasi Penyusutan/Depresiasi Aktiva Tetap dengan mengunakan metode saldo menurun berganda

d. Simulasi Penyusutan/Depresiasi Aktiva Tetap dengan mengunakan metode jumlah angka tahun

\section{KESIMPULAN}

Melalui kegiatan ini laporan keuangan Yayasan Darul Falah sudah balance (seimbang) dan mitra dapat menjelaskan maksud setiap akun/pos keuangan serta dampaknya terhadap neraca disetiap penginputan transaksi dijurnal sehingga dengan penyusunan laporan keuangan yang professional oleh SDM mumpuni maka, dapat lebih meningkatkan kepercayaan pihak internal dan pihak eksternal yayasan (ummat) terhadap dana yang telah didonasikan untuk pengembangan yayasan. Disamping itu, efektivitas pengabdian ini disarakan pula dengan adanya record zoom claud meeting 
yang telah di upload via youtube dapat menjadi referensi untuk dipelajari kembali kapanpun dan dimanapun.

\section{DAFTAR PUSTAKA}

Aldiansyah dan Lambey. L. (2017). Penerapan PSAK No. 45 Revisi Tahun 2015 Pada Yayasan Madrasah Ibtidaiyah Baitul Makmur Kota Kotamobagu. Jurnal Accountability, Vol. 06, No. 01, Hal. 92-102.

Amin. A. dan Astuti. N. P. (2019). Pelatihan Laporan Keuangan Syariah Bagi Entrepreneur Muda Di Makassar. Al Khidmat: Jurnal Ilmiah Pengabdiah Kepada Masyarakat, Vol. 02, No. 02. Hal. 01-04.

Anand. Dev. (2018). Penerapan Penyusunan Laporan Keuangan Yayasan Berdasarkan Psak 45. Jurnal Kajian Akuntansi, Vol. 02, No. 02, Hal. 160-177.

Biduri dkk. (2020). Pendampingan Implementasi Sistem Pencatatan Akuntansi Sekolah Bagi Dan SMK Nurul Huda Kepadangan Kabupaten Sidoarjo. Jurnal Terapan Abdimas, Vol. 05, No. 01, Hal. 114-118.

Nizaruddin dkk. (2020). Pelatihan Pembuatan Media Untuk Pembelajaran Jarak Jauh. Jurnal Abdimas Bina Bangsa, Vol. 01, No. 01, Hal. 98-106.

Syaifullah. H dan Idrus. A. (2019). Manajemen Pengembangan Wakaf Produktif Era Digital Di Lembaga Wakaf Bani Umar. Al Khidmat: Jurnal Ilmiah Pengabdiah Kepada Masyarakat, Vol. 02, No. 02. Hal. 05-14.

Utomo. R., dan Qomariah. I. N. (2014). Penerapan Psak No 45 Pada Laporan Keuangan Yayasan Penolong Anak Yatim Dan Miskin Perguruan Darul Islam Di Kota Gresik Untuk Mewujudkan Akuntabilitas Keuangan. Jurnal Gema Ekonomi, Vol. 03, No. 02, Hal. 230-241. 